\title{
Os Suábios do Danúbio e a geopolítica de ocupação do território - da Europa ao Brasil
}

\author{
The Danube Swabians and the territory occupation geopolitics - from \\ Europe to Brazil
}

\author{
Márcia da Silva'(i), João Matheus Afinovicz de Lima'® ${ }^{\circledR}$, Larissa Aparecida \\ Dionizio' \\ ' Universidade Estadual do Centro-Oeste (UNICENTRO), Departamento de Geografia, Guarapuava, PR, \\ Brasil
}

\section{RESUMO}

Suábios do Danúbio é um termo coletivo utilizado para denominar a população de língua alemã que ocupou e ocupa vários países do sudeste da Europa, no vale do rio Danúbio. A maior parte dessa população é descendente de imigrantes recrutados como colonos, para repovoar determinadas áreas da Europa após a expulsão do Império Otomano, no século XVIII. A saída dos suábios da Europa está intimamente ligada às consequências da Primeira Guerra Mundial (1914-1918) e, principalmente, da Segunda Guerra Mundial (1939-1945), mas também a outros fatores, ainda na Europa, os quais serão apresentados como forma de expressar o papel do "estar líquido" do território a partir de um fenômeno, a mobilidade humana. É por este processo enquanto deslocamento que este artigo objetiva apresentar as histórias dos suábios pela leitura geopolítica do território ou da desterritorialização e reterritorialização dos mesmos ao longo do rio Danúbio. O texto é conduzido pela abordagem histórico-geográfica e apresenta, ainda, experiências da vida e da vivência da colonização suábia em Guarapuava, no Paraná, Brasil.

Palavras-chave: Suábia; Danúbio; Europa; Brasil; ocupação do território

\section{ABSTRACT}

Danube Swabian is a collective term used to describe the German-speaking population that occupied and occupies several countries in southeastern Europe, in the Danube river valley. Most of this population is descended from immigrants recruited as settlers to repopulate 
certain areas of Europe after the expulsion of the Ottoman Empire, in the 18th century. The Swabians departure from Europe is closely linked to the consequences of the First World War (1914-1918) and, especially, the Second World War (1939-1945), but also to other factors, still in Europe, which will be presented as a way of expressing the role of the territory's "being liquid" from a phenomenon, the human mobility. It is through this process as displacement that this article aims to present the stories of the Swabians through the geopolitical reading of the territory or their deterritorialization and reterritorialization along the Danube River. The text is conducted by the historical-geographical method and also presents experiences from the life and the Swabian colonization in Guarapuava, Paraná, Brazil.

Keywords: Swabia; Danube; Europe; Brazil; territory occupation

\section{INTRODUÇÃO}

Este texto aborda o caminhar geopolítico dos suábios do Danúbio ${ }^{1}$, na Europa, até o pós-Segunda Guerra Mundial, tendo por objetivo apresentar "fragmentos das histórias" 2 dos suábios pela leitura geopolítica do território ou da desterritorialização e reterritorialização dos mesmos ao longo do rio Danúbio. E por que o interesse em estudar esse grupo especificamente? Porque os denominados suábios do Danúbio fazem parte das últimas levas de imigrantes europeus chegadas ao Paraná e que, na região Centro-Sul desse estado, imprimiu uma lógica diferenciada de atividade econômica, de identidade cultural, de relações de poder com os já estabelecidos e de formação do território. Os suábios do Danúbio são descendentes de alemães que chegaram ao Brasil no início da década de 1950, instalando-se em Guarapuava, mais especificamente no distrito de Entre Rios. Atualmente, o grupo remanescente é composto por seus descendentes.

\footnotetext{
"Somente a partir de 1922 o termo "Suábios do Danúbio" começou a ser utilizado como denominação coletiva para os grupos de etnia alemã do antigo Império Austro-Húngaro, que naquele momento já estava dividido em várias nações. Todos aqueles que desciam o rio Danúbio para colonizar novas terras passaram a usar essa denominação, mesmo não sendo originários da região da Suábia, mas de outras províncias do reino alemão que embarcavam na cidade suábia de Ulm (ELFES, 1971).

2 O método geográfico-histórico, no texto, teve o papel de conduzir as narrativas, no sentido de compor abordagens que possibilitam a investigação de uma problemática de cunho espacial engendrada de forma relacional ao tempo, buscando empiricizá-lo (ABREU, 2010).
} 
A saída dos suábios da Europa e sua vinda ao Brasil está intimamente ligada às consequências da Primeira Grande Guerra Mundial (1914-1918) e, principalmente, da Segunda Grande Guerra Mundial (1939-1945), mas também a outros fatores, ainda na Europa, os quais serão apresentados como forma de expressar o papel do "estar líquido" do território a partir de um fenômeno, a mobilidade humana.

Para pensarmos o movimento realizado pelos suábios ao longo de suas histórias, como aqui abordado, nos posicionamos a partir de Cresswell (2006), que compreende este conceito como o movimento socialmente produzido a partir de três momentos ${ }^{3}$ relacionais, dos quais nos asseguramos ao fato de "[...] mobility is practiced, it is experienced, it is embodied. Mobility is a way of being in the world" (CRESSWELL, 2006, p. 3).

Este conceito e sua vinculação ao tema foi selecionado com a intenção de contribuir para repensarmos parte da história dos suábios do Danúbio, posto estes serem reconhecidos como agregadores de poderio econômico, do apego e da responsabilidade com o trabalho, da aversão a política partidária, da perfeição como grupo familiar tradicional, da preservação da identidade e dos costumes, e como povoado de descendência alemã, no Brasil, ao contrário do controle social e territorial que passaram em território europeu.

O texto está dividido em três partes que discorrem sobre a origem dos povos germânicos, os caminhos dos suábios do Danúbio pela Europa, impulsionados e resultantes das duas guerras mundiais e finaliza-se com relatos de experiências de moradores suábios e seus descendentes, de Guarapuava, mas relativos a geopolítica do Território ainda quando encontravam-se na Europa.

\footnotetext{
3 As outras duas formas de mobilidade humana abordadas por CRESSWELL $(2006$, p. 3) são: [...] First, when talking of human mobility, we are talking about mobility as a brute fact-something that is potentially observable, a thing in the world, an empirical reality. [...] Second, there are ideas about mobility that are conveyed through a diverse array of representational strategies ranging from fi Im to law, medicine to photography, literature to philosophy.
} 


\subsection{A origem dos povos germânicos - as migrações da Antiguidade e da Idade Média}

Os povos germânicos, dos quais descendem os suábios do Danúbio, viveram na Antiguidade, um longo período entre 4.000 a.C até 476 d.C., sendo a formação social dos mesmos bastante variada e complexa. Nesse texto o recorte espacial delimita esses povos aos que habitaram ou imigraram para o Leste Europeu no período anterior a chegada dos suábios à região.

O grande palco da história dos povos germânicos vincula-se aos rios e mares da Europa. A água, nessa síntese da história, é símbolo de vida e morte, poder e submissão. Muitas vezes usada como divisa geográfica de um Reino ou Estado, foi usada para subjugar e dominar muitos povos. Exercer domínio sobre pontos estratégicos do território, como às margens dos rios Elba, Reno, Meno, Danúbio, ou a saída para o mar, era símbolo de poder, sem contar as possibilidades reais de outras conquistas.

Ao trazermos o conceito de território, cabe indicar que o elemento epistêmico que a ele nos conduz fundamenta-se em na concepção de Haesbaert (2004), ou seja, uma dimensão espacial que se revela em processos de dominação mais concretos, tanto pela produção material, quanto em termos jurídico-políticos. Ainda de acordo com o autor, o território pode ser, também, um espaço apropriado imaterialmente, na produção de identidades, subjetividades e simbolismos. Assim, o território assume um viés multidimensional (político-jurídico, econômico e culturalista) e os movimentos dos agentes e grupos, como os suábios, manifesta processos como os de desterritorializações e (re)territorializações.

É nesse sentido que a maior parte da história, não apenas da Europa, mas do Mundo Antigo e, principalmente, da Idade Média, envolveu de alguma forma esse elemento: a água, que levou várias civilizações à guerras por territórios por ela margeados, tornando-os pontos estratégicos para a sobrevivência das 
populações. Em relação a este processo, os suábios também foram agentes significativos.

Guerras interferem profundamente na vida dos povos. Afirmação válida para as guerras do Império austro-húngaro contra os turcos, ocorrido entre 1683 e 1718, e que resultaram para a Áustria numa expansão territorial e no estabelecimento de condições para a emigração de alemães, dos atuais suábios do Danúbio, de suas terras junto ao Reno, Meno e Danúbio. Radicaram-se no baixo Danúbio junto ao Teiss e ao Marosch, conforme planos estabelecidos pela Câmara da corte Imperial de Viena. [...] Após a Primeira Grande Guerra Mundial, a região foi dividida entre Hungria, lugoslávia e Romênia. Ao fim da Segunda Guerra Mundial, quando avançava o exército vermelho, muitos suábios do Danúbio, da Romênia, Hungria e lugoslávia abandonaram as terras onde se haviam radicado, fugindo rumo ao Oeste, tão somente para salvar suas vidas (COOPERATIVA AGRÁRIA MISTA ENTRE RIOS LTDA, 1979, p. 5).

Além das guerras de conquistas, a história dos povos germânicos está também ligada a migrações, pequenas ou grandes, mas constantes, que tinham como finalidade ampliar territórios, sendo frequentes as anexações de Reinos, Ducados, Principados, Papados e Bispados (MONTGOMERY, 1999).

Os chamados povos bárbaros tinham descendência alemã, além de outras, e formaram o princípio da história dos povos germânicos, que marcaram a história no século IV a.C., ficando o período conhecido como das invasões bárbaras, finalizadas no século VI. Eram seis milhões de quilômetros quadrados que iam desde Portugal até o Iraque, e da Inglaterra até o Norte da África (DIAS, 2005).

Os teutões, um dos primeiros povos invasores/conquistadores das regiões mediterrâneas, são exemplos de povos bárbaros que se consolidaram por esse processo, com o apoio da Igreja, já que eram oriundos de uma Ordem de cavaleiros militares da Alemanha, sendo as terras conquistadas cedidas, posteriormente, à propriedade do Papado de Gregório IX, embora continuassem sob o controle da Ordem (MONTGOMERY, 1999).

O termo "bárbaro", usado para definir os germânicos, era carregado de preconceito, sendo originado da palavra barbaroi (aquele que não falava grego), numa visão de discriminação ao estrangeiro. A sua utilização, em Roma, passou a 
ser frequente quando os romanos passaram a contratar germânicos para defender seu Império. A aparência mais grotesca dos germânicos, geralmente com forte estrutura óssea, farta profusão de cabelos loiros ou avermelhados, traços mongóis dos nômades e roupas de pele eram argumentos do preconceito (DIAS, 2005).

Os bárbaros eram, então, os incivilizados, aqueles que tinham hábitos não românicos e terem a cerveja como bebida predileta, e não o vinho, como os romanos. O cheiro forte dessa bebida incomodava os romanos, acostumados ao requintado paladar do bom vinho gaulês (francês). Os romanos sabiam que os germânicos habitavam o outro lado das margens dos rios Reno e Danúbio e com isso denominavam parte dos Germânicos (ostrogodos, visigodos, vândalos, suevos, lombardos, anglo-saxões e alamanos), apesar de falarem a mesma língua, aqueles oriundos das proximidades do rio Danúbio, com o qualificativo de germânicos do Danúbio (YUDENISTSCH, 2005). Foi nesse sentido que a maioria das denominações dos povos germânicos tinha algo a ver com o local para o qual iam ou vinham.

Os povos germânicos da Antiguidade tinham características laborais voltadas para a agricultura (cultivo de cereais como aveia e centeio, introduzidos por eles na Europa) e a criação de animais, bem como técnicas de ligas metálicas e de fabricação de tonéis (DIAS, 2005).

De acordo com Montegmery (1999), a formação do Santo Império na Alemanha, no século $X$, propiciou as Ordens germânicas o ímpeto conquistador, tendo como finalidade incorporar as populações eslavas e magiares aos cristãos, especialmente em direção ao Leste Europeu, formando o que Elfes (1971) denomina de um reino germânico-magiar de intencionalidades à expansão econômica das populações alemãs.

A princípio esse movimento foi lento, ganhando importância somente ao ultrapassar o rio Elba, o que só ocorreu no século XI. Nas palavras de Albuquerque, Reis e Carvalho (1980, p. 93), "os margraves procuravam chamar para suas terras, despovoadas, colonos alemães que vinham em grande número da Wersália e da Frísia. Os margraves vendiam os lotes e fundavam cidades". 
Os nômades hunos, por exemplo, são parte da história das migrações germânicas na Europa Ocidental, e dominaram praticamente toda a Alemanha durante o reinado de Átila, permanecendo em grande número até por volta de 378 d.C. (ENCICLOPÉDIA BARSA, 1987). Os hunos estavam entre os povos que tinham características guerreiras e eram bastante temidos, sendo eles os responsáveis por parte da decadência do Império Romano do Ocidente, sob o domínio de Átila, rei em 370 d.C. (YUDENISTSCH, 2005).

O Império huno expandiu-se como resultado das constantes campanhas de guerra, bem como pelo abandono, mais tarde, das características nômades dos guerreiros, que passaram a adotar costumes germânicos, como o uso da catapulta, aríete e infantaria desmontada quando sua maior arma era o cavalo. A perda dos antigos hábitos foi o que os levou a quase extinção, suportada pela fixação à terra de alguns grupos, como o costume dos germânicos (YUDENITSCH, 2005).

A intervenção dos hunos no Império Romano fez com que este tivesse suas fronteiras muito reduzidas, apesar de, no século II, o Império Romano ter a maior extensão de todos os seus tempos, abrangendo a Inglaterra, França, Grécia, Hispânia, Itália, Armênia a Ásia Menor e parte da África (YUDENITSCH, 2005). O Império Romano do Oriente desapareceu após anos de decadência, sob a conquista turco-otomana, em aproximadamente 1453 (VICENTINO, 1996).

Os povos margraves tinham, em parte, características de comportamento agressivo [...] "eram povos de origem asiática, provavelmente mongóis, que se estabelecerem na Europa Oriental" que conquistaram as terras búlgaras, a Península Itálica, a Moravia (atual República Tcheca) e a Bavária (GIBRIN, 2005).

Outros vários povos nômades e bárbaros expandiram-se nos 12 séculos antes de Cristo ao longo da região dos Bálcãs, sendo que alguns também foram responsáveis, mais tarde, pela formação de outras nações, bem como pela queda do próprio Império Romano. A figura 1 mostra a dimensão do Império Romano no auge de maior extensão territorial. 
Figura 1 - Império Romano

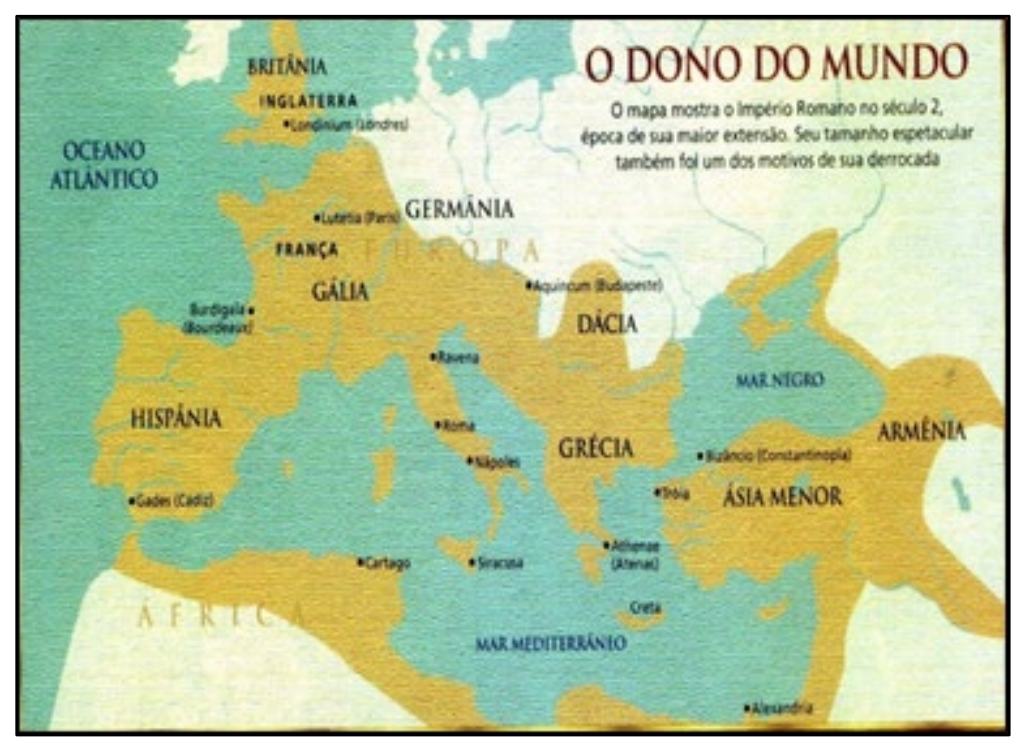

Fonte: Coleção Grandes Guerras/Org.: Rodrigues, Isabela (2005).

Os povos eslavos, por sua vez, segundo Guilherme (2005), chegaram ao Leste Europeu por volta do século V, em sucessivas invasões migratórias, durante 500 anos, fruto do excedente populacional que os levou a essas frequentes migrações em busca de novas terras para a prática agrícola e pastoril.

O processo migratório levou os eslavos a três direções em três etapas diferentes: a primeira para a Alemanha, ao longo do curso do rio Elba, ocupando as terras que hoje correspondem à República Tcheca, Eslováquia e Polônia, terras que foram ocupadas pelos eslavos do Oeste. A segunda levou os eslavos do Leste a juntaram-se às tribos turcas e iranianas e ocupar a Bielo-Rùssia e a Rússia. A terceira etapa aconteceu com os eslavos do Sul, os quais colonizaram as costas do Mar Negro e do Mar Adriático, correspondentes as atuais regiões da Sérvia, Bósnia, Croácia, Eslovênia, Macedônia, Moldávia, Bulgária, norte da Grécia e Montenegro.

A grande conquista dos povos eslavos aconteceu em 907, quando o exército do príncipe Kiev, formado por 80 mil homens, sob o comando de Oleg (líder das tribos eslavas da região da atual Ucrânia) invadiu Constantinopla, capital do Império Bizantino (GUILHERME, 2005). 
Constantinopla tem localização estratégica entre o Ocidente e o Oriente. Assim, em 911, o Império Bizantino assinou um acordo favorável à nação eslava, a qual, a partir daquele momento, teria o controle da rota comercial desde o Oriente até o Mar Negro e o Mar Báltico.

No lado oriental, os russos eram considerados eslavos puros, já, no lado ocidental, existiam elementos alógenos. O Leste da Rússia era considerado primitivo e o Oeste era considerada a Rússia colonizada. Durante os séculos IV a XII, os territórios ocupados por esses grupos ficaram sujeitos a invasões. Os lituanos conquistaram os ocidentais e se uniram aos poloneses para, em 1386, formar uma forte coalizão que derrotou os Cavaleiros Teutônicos, em 1410, em Tanenberg. Em 1466, criaram e impuseram o Tratado de Torn, que tornava os teutões relis feudatários do rei da Polônia (ALBUQUERQUE; REIS; CARVALHO,1980).

O grupo oriental foi subjugado pelos tártaros-mongóis, que exigiam tributos, mas não intervinham nas comunidades eslavas. O resultado dessas duas conquistas deixou influências germânicas e polonesas nos principados do Oeste, e nos principados do Leste influências muçulmanas e asiáticas. Esses núcleos formaram, mais tarde, a grande Rússia de traços mongóis, apesar da língua e dialeto comuns. É possível observar na figura 2, o avanço dos povos eslavos pela Europa. 
Figura 2 - Rota de expansão dos eslavos na Europa

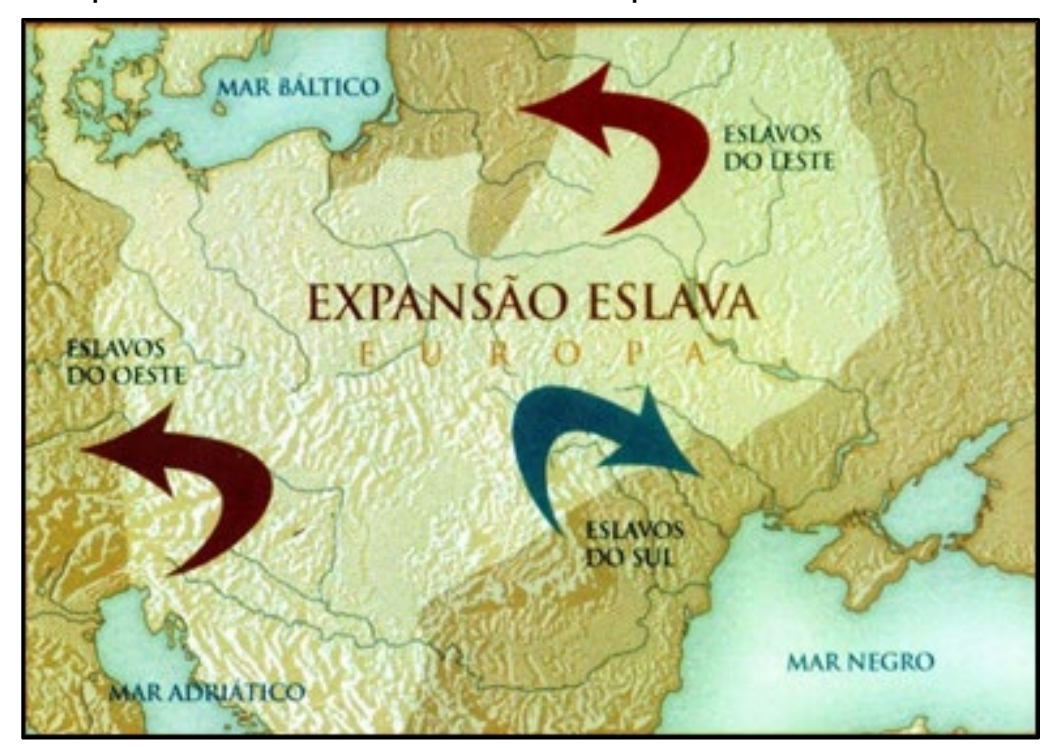

Fonte: Coleção Grandes Guerras (2005)/Org.: Nilson, Paulo (2005).

Já os povos muçulmanos tiveram seu período de expansão sobre o Ocidente durante a Dinastia Omíada, em 711. Ao adentrar à Península Ibérica, subjugou os povos visigodos que habitavam a região e, com isso, passaram a dominar o norte da África, a Península Ibérica e o Mar Mediterrâneo.

Esse domínio, exercido pelos árabes sobre o Mediterrâneo, praticamente impedia a relação de atividades comerciais entre os sobreviventes do que era anteriormente o Império Romano do Ocidente. Os árabes expandiram seus domínios até as fronteiras da China (VICENTINO, 1996). A figura 3 ilustra a expansão muçulmana pela Europa. 
Figura 3 - Expansão Muçulmana pela Europa

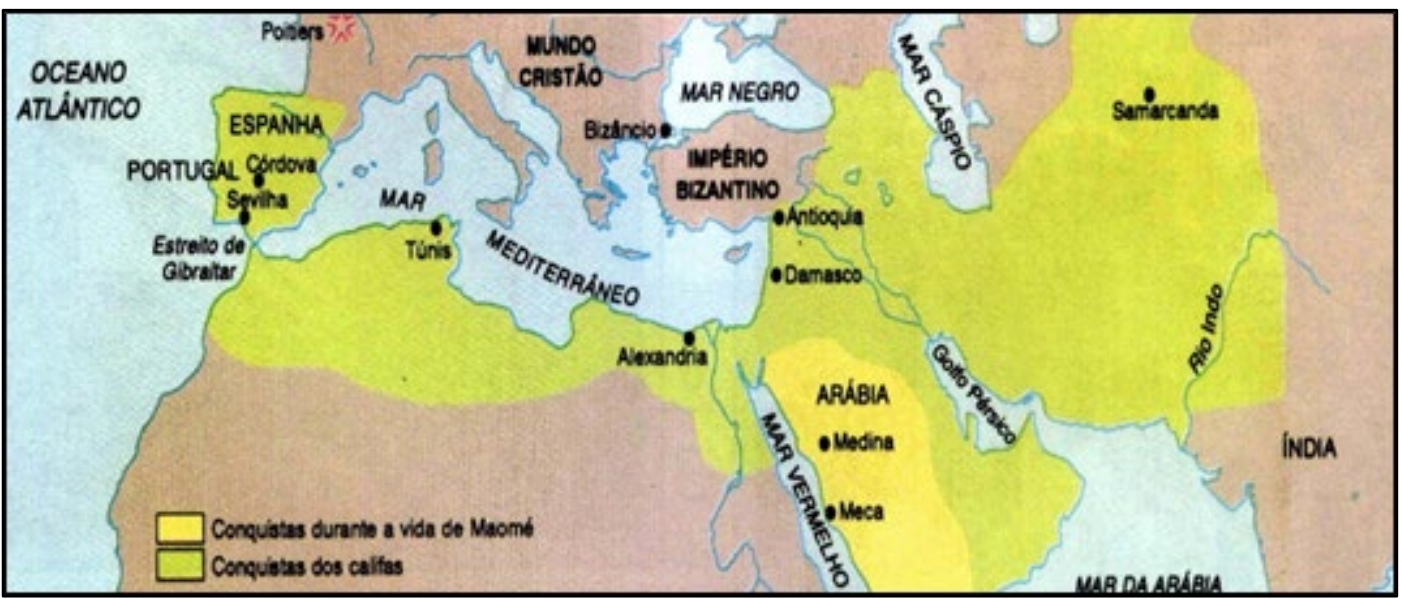

Fonte: Vicentino (1996). /Org.: Nilson, Paulo (2005).

Os povos germânicos, como observado, foram/são constituídos por povos de diferentes partes dos continentes europeu e asiático. A tentativa de unificação dos povos germânicos, na Europa, ocorreu por mais de uma vez, sem muito sucesso. Na Idade Média o Império de Carlos Magno passou a ser denominado de Sacro Império Germânico (MONTGOMERY, 1999), justamente pelo fato de Carlos Magno utopicamente buscar a unificação das línguas e dos povos germânicos.

Portanto, surgiu ainda na Idade Média a ideia de reino alemão unificado e de purificação da raça alemã, apesar de a grande tentativa ter se dado muito posteriormente, via Reichs, conceito de Hitler para a formação de um Reino Alemão (MONTGOMERY, 1999).

\section{OS CAMINHOS DOS SUÁBIOS DO DANÚBIO PELA EUROPA}

Os alemães cujos descendentes ganhariam a denominação de Suábios do Danúbio foram aqueles que chegaram ao vale do baixo Danúbio ainda na Idade Média, quando o Reino Austríaco foi anexado à Hungria, após o retrocesso da ocupação territorial dos turcos. Muitos outros países passaram a fazer parte deste Reino que agregara uma extensão territorial com 38 Estados oficiais, a partir do congresso de Viena (1814) (CONGRESSO DE VIENA, 1814). 
Para preservar o território conquistado havia a necessidade de o repovoar, a fim de evitar uma nova invasão turca, pois o Império Húngaro era formado por povos nômades que não se fixavam à terra, o que trazia constantes problemas com invasões estrangeiras. A condição mais rápida para uma ocupação densa seria incentivar a imigração, o que de fato aconteceu (ELFES, 1971).

Convidados pelo Império Húngaro a ocupar esta região, suábios e bávaros começaram a imigrar. A formação desses povos era bastante diversa, mas em especial com grupos étnicos alemães de tradição camponesa e agrícola. Segundo Elfes (1971), o Imperador Leopoldo, da Áustria, após expulsar os turcos otomanos de mais uma área do Danúbio, na região do Danúbio central, tornou-se o maior proprietário de terras daquela região, como resultado da transferência das mesmas ao Império. Outros segmentos, como soldados e heróis de guerra favoráveis ao Imperador, foram beneficiados com grandes concessões de terras.

Ainda de acordo com o autor, a história dos suábios do Danúbio e de sua identidade cultural, então, está de tal forma vinculada à história da Alemanha, da Áustria e de outros países do sudeste da Europa, como a Romênia, a Hungria e a antiga lugoslávia, em um período que abrange do século XVII a primeira metade do século XX (ELFES, 1971, p.27).

O termo suábios do Danúbio é o coletivo para a população de língua alemã que viveu especialmente no vale do rio Danúbio, sendo a maioria descendente de imigrantes recrutados como colonos, no século XVII, para repovoar a área após a expulsão dos habitantes do Império Otomano.

Essa colonização ocorreu como resultado de convite dos senhorios húngaros, durante o reinado dos Habsburgos, imperadores húngaros do "Império da Nação Alemã, aos povos que faziam parte da região chamada "Suábia", formada por povos germânicos e eslavos. Esses suábios ficaram conhecidos, segundo Koop (2003), como "Ungarländische Deutschen" (alemães-húngaros). Com o fim do Império Austro-Húngaro, pelo exército das nações aliadas, após a Primeira Guerra Mundial, 
as regiões as quais os alemães se instalaram foram divididas surgindo os países Hungria, Romênia e lugoslávia.

Assim, a história da grande imigração dos suábios do Danúbio para o Império Austro-Húngaro aconteceu em três grandes etapas.

A primeira, nomeada de "Karolinische Ansiedlung" foi direcionada para a região da atual Romênia, do Conde Mercy, entre 1718 e 1735 (JAEGER, 1998). A segunda, nomeada de Maria Theresianische Ansiedlung, foi dirigida pela Imperatriz Maria Teresa, que teve como primeiro ato povoar suas terras com colonos alemães que viviam próximos aos rios Marosch, Danúbio e Theiss, entre os anos de 1740 e 1770. A terceira etapa, de acordo com Paikert (1967), foi chamada de "Josephinische Ansiedlun" e ocorreu por volta de 1780 e 1790, quando José II introduziu mais de 60.000 migrantes que formaram vilas e prosperaram economicamente na região, que passou a ser conhecida como o "celeiro da Europa", pois, uma grande parte dos solos nos quais os imigrantes se instalaram eram pântanos, que foram drenados e transformados de solos antes improdutivos em vastos campos agricultáveis de trigo e extensos parreirais de uvas (FRIEDRICH, 2005).

Após 1789, a colonização patrocinada pelo governo foi interrompida, mas alguns colonos continuaram a chegar à Hungria até o século XIX (CLARKSON, 1997). A linha do tempo a seguir (figura 4) apresenta a ocupação suábia na Europa de 1683 a 1920. 
Figura 4 - Suábios do Danúbio - ocupação do território europeu ao longo do tempo

\begin{tabular}{|c|c|c|c|c|}
\hline $\begin{array}{l}\text { Império Turco- } \\
\text { Otomano } \\
\text { ocupava parte da } \\
\text { Hungria } \\
1683\end{array}$ & $\begin{array}{l}\text { Primeira grande } \\
\text { imigraçăo suábia } \\
\text { para regiōes ás } \\
\text { margens do rio } \\
\text { Danúbio } \\
1712\end{array}$ & $\begin{array}{l}\text { Terceira grande } \\
\text { imigraçăo suábia para } \\
\text { regiobs às margens do } \\
\text { rio Danúbio } \\
1780\end{array}$ & \multicolumn{2}{|c|}{$\begin{array}{c}\text { Fim da Primeira Guerra } \\
\text { Mundial } \\
1918\end{array}$} \\
\hline $\begin{array}{l}1687 \\
\text { Turcos-Otomanos } \\
\text { derrotados pelo } \\
\text { Império Austriaco. } \\
\text { Primeiros imigrantes } \\
\text { suábios iniciam o } \\
\text { povoamento de } \\
\text { regióes às margens } \\
\text { do rio Danúbio }\end{array}$ & $\begin{array}{l}\text { Segur } \\
\text { imigraça } \\
\text { regioes } \\
\text { rio }\end{array}$ & $\begin{array}{l}0 \\
\text { grande } \\
\text { lábia para } \\
\text { argens do } \\
\text { ábio }\end{array}$ & $\begin{array}{c}1914 \\
\text { Inicio da Primeira } \\
\text { Guerra Mundial }\end{array}$ & $\begin{array}{c}1920 \\
\text { Tratado de Trianon"e } \\
\text { divisăo do território } \\
\text { Austro-Húngaro e das } \\
\text { regióes habitadas pelos } \\
\text { suábios }\end{array}$ \\
\hline
\end{tabular}

Fonte: CLARKSON, S. (1997).

Nesse período havia seis regiões que compunham o território dos suábios do Danúbio ${ }^{4}$, denominadas Southwest Hungarian Mountain, Sathmar, SlavoniaSyrmia, Schwäbische Türkei, Batschka e Banat. Porém, como observado na figura 5, as regiões de Banat, Batschka e Schwäbische Türkei eram as mais importantes em aspectos econômicos e de formação de cidades e vilas.

4Informações cedidas a Profa. Dra Márcia da Silva, em 2014, pelo Museu de Haar, na Alemanha, nomeado de Haus der Donauschwaben (Casa dos suábios do Danúbio ou Haus der Donauschwaben ou Casa dos Suábios do Danúbio em tradução ao português). 
Figura 5 - Suábios ao longo do rio Danúbio (séculos XVIII a XX)

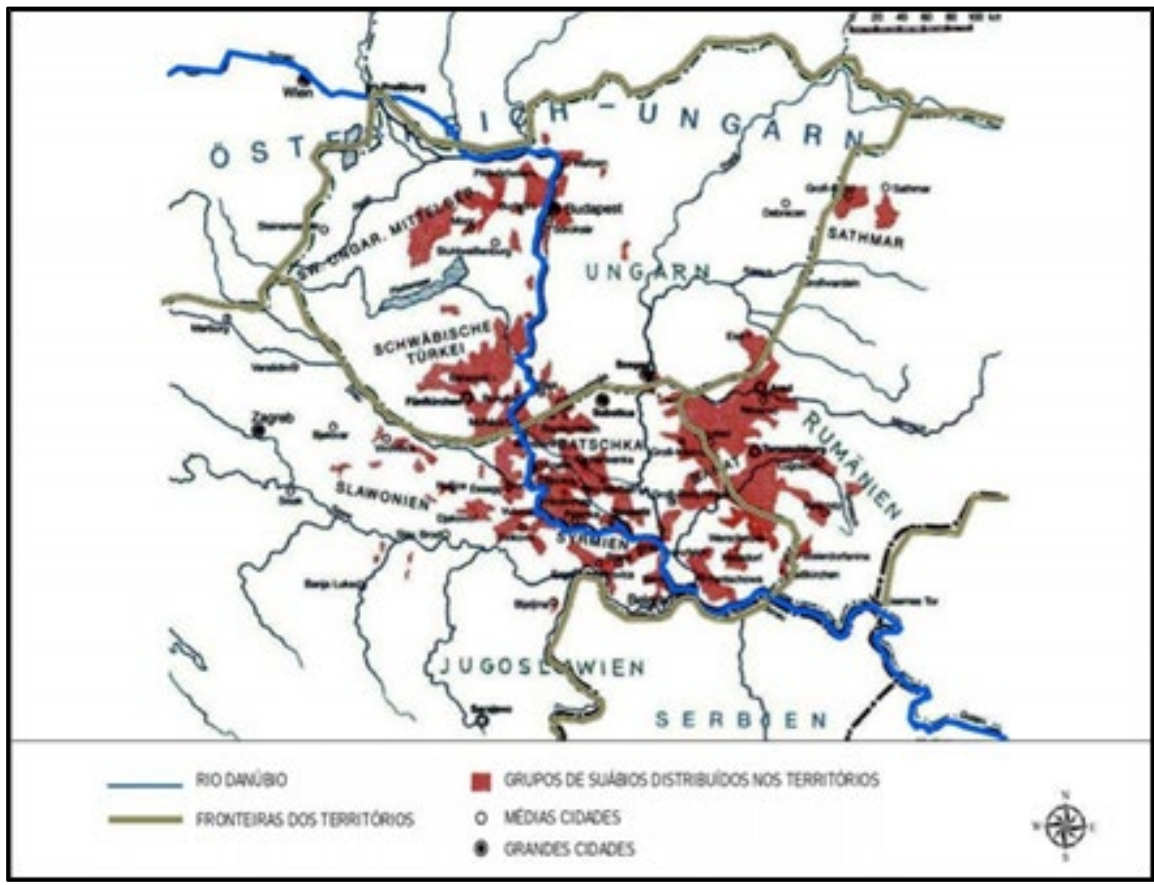

Fonte: KOOP, H. (2003).

O destaque do domínio do território, nesse período, está no Império AustroHúngaro, no século XVIII, no qual ocorre a base de como era a organização suábia nas regiões centrais do Império no contexto do extenso rio Danúbio. Na figura 5, a ocupação realizada por populações suábias encontra-se nas regiões centrais do Império Austro-Húngaro, mas mudando as fronteiras se re-configurando após a Primeira Guerra Mundial.

É possível observar, ainda na figura 5, a região da Schwabische Turkei, após a planície da Panônia, ao sul do lago Balaton, entre os rios Danúbio e Drava, parte da Hungria. Já a região de Banat estava ao norte do rio Danúbio, na Romênia. Batschka estava ao norte do Danúbio, entre os rios Danúbio e Tisza, e pertencia a ex-lugoslávia

O repovoamento do império Austro-Húngaro naquele momento, era de povos fiéis ao imperador no sentido de fortalecer seu poder. Esta condição se dava em razão de divergências existentes com os povos húngaros, em razão das grandes migrações e da grande mistura de povos germânicos (JAERGER, 1998). 
Essa migração maciça se deu, principalmente, à acentuada superpopulação e fome que assolava os feudos da Alemanha e de outras nações na época. O sistema hereditário de partilha de terras e a política agrária estavam reduzindo as propriedades rurais que, mesmo quando produziam bem, ainda não era o suficiente para o sustento das famílias.

As propriedades tornaram-se improdutivas, conforme Elfes (1971, p. 16): “Há aldeias nas quais não trabalha mais o arado, e outras nas quais, por ser impossível reduzir-se ainda mais os lotes, dá-se às filhas árvores frutíferas isoladas como dote matrimonial". Nessas condições, o governo austríaco sugeriu ao Reino Alemão, em 1849, que orientasse uma forte imigração para a Hungria, como de fato aconteceu.

O sucesso dos camponeses alemães, naquela região, levou muitos proprietários eslavos e húngaros a recrutarem ainda mais imigrantes, oferecendoIhes muitas vantagens, inclusive de liberdade cultural.

Durante o tempo da migração alemã para o sudeste do Danúbio, que durou entre 150 e 250 anos, estes dominaram o mercado de trabalho, fundaram minerações e derrubaram grandes florestas. Apesar de terem enfrentado epidemias de cólera e peste que mataram aproximadamente $40 \%$ dos colonos, o aumento do número de filhos, mais tarde, superou o número de mortes (ELFES,1971). O sucesso da imigração foi tão grande, que na metade do século XIX, período do Império Austro-Húngaro, já somavam 400.000 pessoas.

Apesar do início difícil, no qual formaram grupos étnicos fechados e autônomos, cultural e economicamente, com o passar do tempo tiveram contatos mais aproximados que resultaram, inclusive, em casamentos mistos, com pessoas de etnias vizinhas, locais e magiares, surgindo cooperações e intercâmbios culturais entre os mesmos. Com o passar dos anos, os imigrantes alcançaram alto nível econômico e de domínio sobre o território e, articulados, conseguiram consolidar a língua alemã como oficial em todo o Império Húngaro.

Esse quadro aparente de amizade perdurou até a queda do Império AustroHúngaro. Segundo Elfes (1971), ao mesmo tempo em que os suábios (alemães, 
romenos, eslovenos, eslovacos, búlgaros e outros) obtinham sucesso econômico, os grupos não alemães (aproximadamente 30\% do total) desenvolviam-se lentamente, mas com capacidade para fazerem surgir, por volta do século XVIII, uma crescente consciência nacionalista.

Esta consciência se observava na germanização ou formação de um estado alemão, na russificação ou formação de um estado russo e na formação de um estado eslavo, que era incentivado por agitações políticas e, mais tarde, tornou-se chauvinista, a ponto de aniquilar o Império Austro-Húngaro e a monarquia dos Habsburgos, presente há tempos naquele território.

\section{AS GUERRAS MUNDIAIS E OS SUÁBIOS DO DANÚBIO}

Apesar das divergências entre os povos sérvios e croatas, como demonstrado, havia um desejo em comum entre eles, o de não possuir mais em seus territórios povos estrangeiros. O crescente nacionalismo que se instalava idealizava unir todos os povos eslavos do Sul (croatas, eslovenos e bósnios) num único reino, sendo os sérvios fortes aliados.

Francisco Ferdinando, herdeiro do trono Austro-Húngaro, era signatário da dinastia Habsburgo e tinha planos anti-húngaros, pois via os magiares como uma ameaça a manutenção do reino germânico e de sua dinastia. Da mesma forma os eslavos, apesar de pertencerem ao Império Austro-Húngaro, viam em Francisco Ferdinando uma ameaça a instalação de um futuro reino eslavo. A figura 6 apresenta a divisão geográfica da Europa em 1914. 
Figura 6 - Divisão do território europeu em 1914

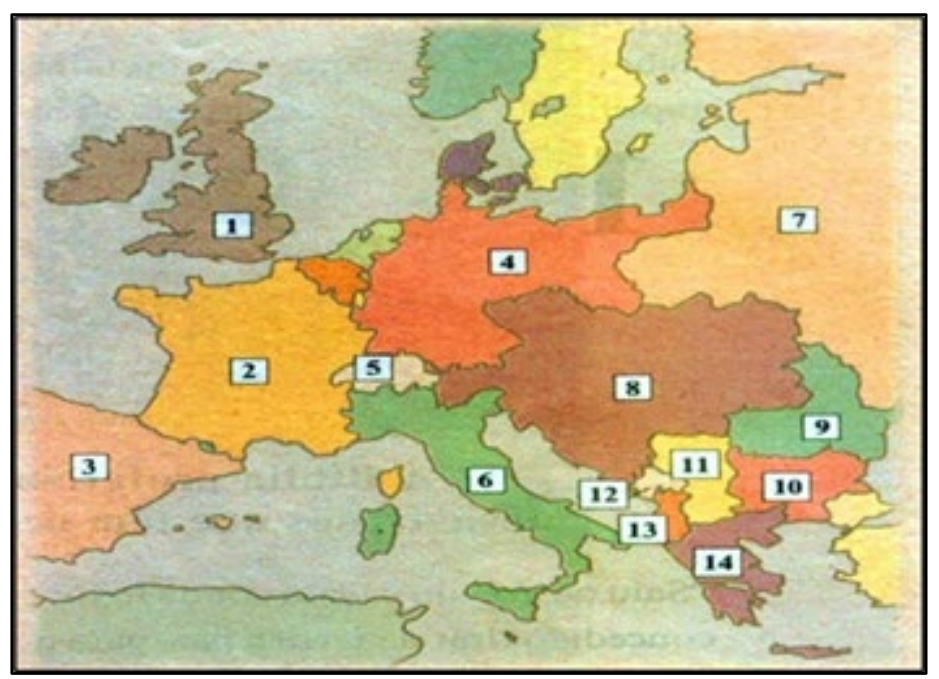

Fonte: Revista Despertai (2014).

Legenda: 1. Grã-Bretanha e Irlanda; 2. França; 3. Espanha; 4. Império Alemão; 5. Suíça; 6. Itália; 7.

Rússia; 8. Áustria-Hungria; 9. Romênia; 10. Bulgária; 11. Sérvia; 12. Montenegro; 13. Albânia; 14. Grécia.

Francisco Ferdinando e sua esposa foram mortos, em 1914, sendo o acontecimento o precursor das batalhas da Primeira Guerra Mundial, mas deixando aberto o caminho para os objetivos dos nacionalistas eslavos. Assim, ao final da Primeira Guerra Mundial, a monarquia Áustro-Húngara estava encerrada, permitindo a Sérvia a união dos povos eslavos (MONTGOMERY, 1999).

[...] com a dissolução da Monarquia dos Hasbsburgo, em 1918, as antigas regiões de colonização alemã foram subdivididas entre as novas potências recém criadas: lugoslávia, Romênia e a nova Hungria, tornando-se os colonos alemães, automaticamente, cidadãos dessas novas nações (ELFES, 1971, p. 19).

Os conflitos que existiam nessa região não eram novos, vinham desde 1871, segundo ELFES (1971), pois lá existiam indícios de apartheid e outros fenômenos sociais, econômicos e estratégicos fronteiriços que faziam surgir constantes micro conflitos. A região dos Bálcãs, no início do século XX, chegou a ser frequentemente chamada de "o canto turbulento da Europa" (FRIEDRICH, 2005).

Na figura 7 podemos observar como estava a divisão do Império AustroHúngaro na Europa em anos que antecederam a Primeira Guerra Mundial. 
Figura 7 - Império Austro-Húngaro - composição étnica e organização política administrativa antes da Primeira Guerra Mundial (1911)

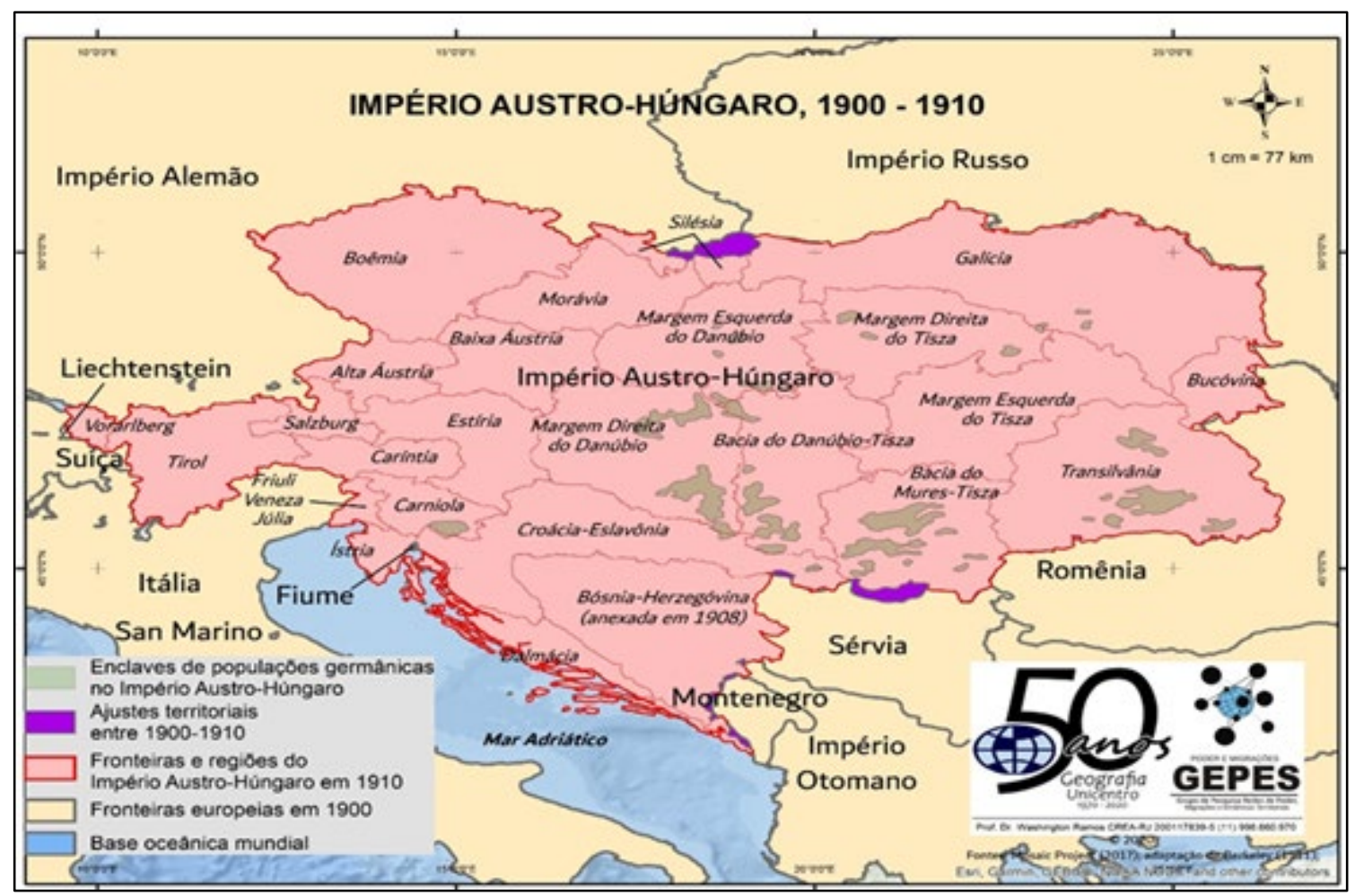

Fonte: SANTOS JUNIOR (2016).

Na figura 8 pode-se observar a localização do Império Austro-Húngaro e podemos observar como ficou dividida as regiões do Império, onde os grupos suábios localizados em Banat, Batschka e na região dos Schwäbische Türkei foram desintegrados, e os habitantes dessas regiões tornaram-se cidadãos de novos Estados após o tratado de Trianon.

Pode-se também observar que a região central da Europa não foi a única que sofreu mudanças e configurações em seu território. Nas regiões ao norte e a nordeste também houve transformações e a dinâmica político-territorial, da mesma forma, foi alterada. 
Figura 8 - Europa pós Primeira Guerra Mundial e Tratado de Trianon (1918-1920)

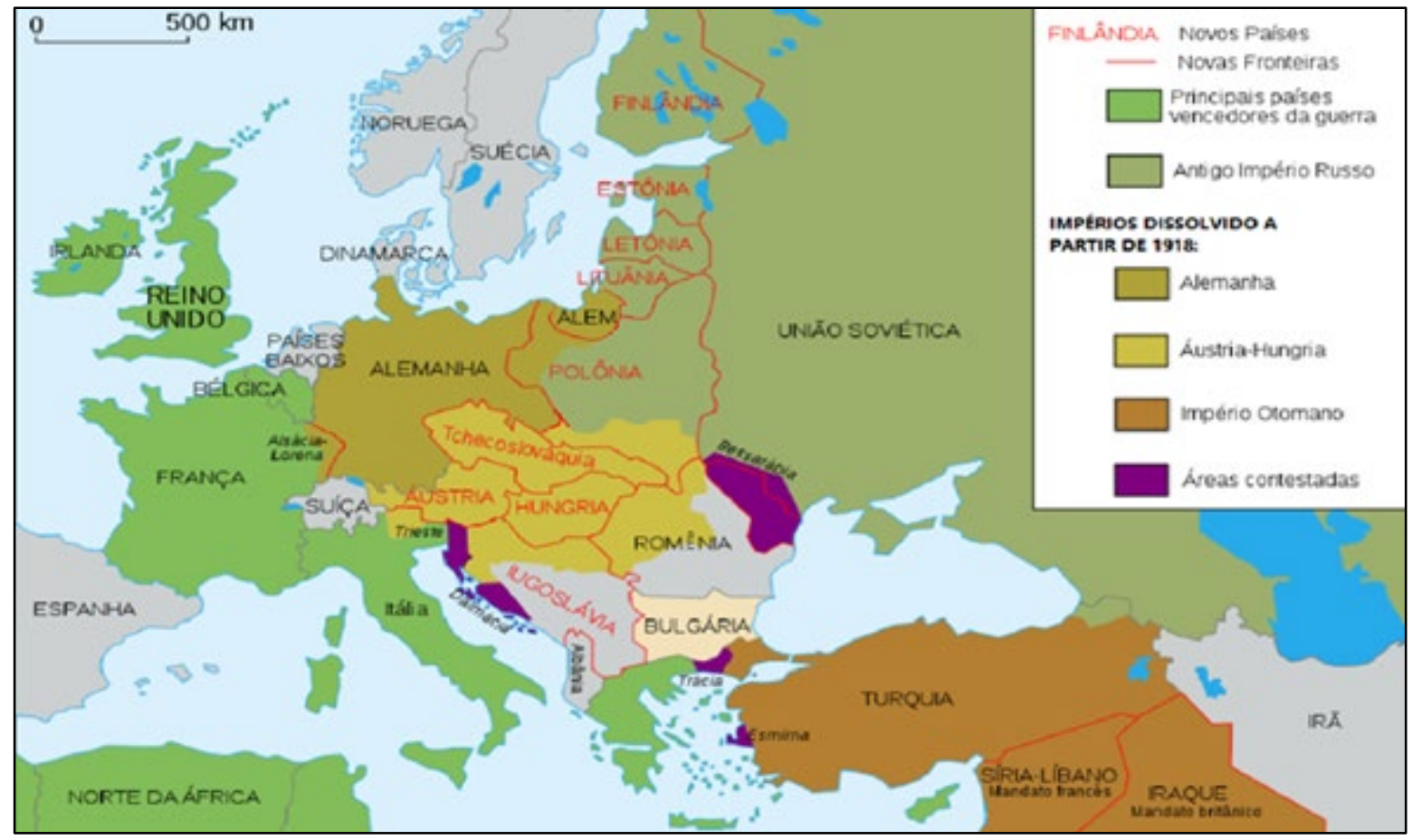

Fonte: KOPP, H. (1974).

Desta forma, a divisão das três regiões mais importantes para o povo suábio, Suábios Turcos, Batschka e Banat foram reconfiguradas, sendo que a dos suábios Turcos passou a pertencer ao Estado da Hungria, a Batschka à lugoslávia e a região de Banat passou a integrar o território da Romênia.

Conforme Jaerger (1998), o fato de alguns jovens suábios aceitarem fazer parte do exército alemão foi o estopim da rivalidade destes com os povos nativos. Entretanto, alguns fizeram a escolha pela facilidade da língua, outros pela obrigatoriedade ou, ainda, espontaneamente. As atrocidades cometidas sob o comando de Hitler fizeram dos suábios da lugoslávia as primeiras vítimas do ódio nazista e igualmente comunista soviético, com aproximadamente 200.000 mil suábios mortos, em sua maioria mulheres, idosos e crianças.

Os suábios da lugoslávia, mais politizados, tentavam manter-se unidos e fazer uso de seus direitos. Em 1920 uniram-se e formaram o Centro Cultural Suábio Alemão, com o lema "Fidelidade ao Estado e ao Povo". Em 1922, criaram a 
Cooperativa Central de Agricultura, a Agrária, tudo por receio de perder sua identidade cultural, o que já vinha acontecendo (KOPP, 1974).

Ainda de acordo com Koop (1974), em junho de 1920, o Tratado de Trianon reduziu em dois terços o território e a população da Hungria. Com a mudança repentina das fronteiras, os húngaros passaram a ser minoria e considerados inferiores em diversos países a eles estranhos, passando a sofrer perseguições.

As ideias revisionistas passaram a fazer parte do povo húngaro, após a Primeira Grande Guerra, em função da perda dos territórios. Para eles a perda era inaceitável, fazendo-se identificar pela expressão "como não, não, nunca", que demonstrava a dificuldade em aceitar os novos limites de seu território. O período entre Guerras aprofundava a aculturação dos suábios na Hungria (KOPP, 1974).

A Segunda Guerra Mundial, no entanto, deu outro rumo à história, não apenas dos suábios, mas também a outros povos. Em 1930, 1,8 milhões de húngaros tinham sobrenome alemão, mas a exigência da assimilação dos povos por parte dos órgãos oficiais reduziu este número para 418.000, ou seja, aqueles que reconheciam o idioma alemão como língua materna (MONTGOMERY, 1999).

Com o Terceiro Reich, no auge do poder de Hitler, e com a prática de uma política de simpatia a quaisquer aliados, os suábios alemães passaram a ter concessões anteriormente negadas. Naquele momento a Alemanha mostrava-se defensora de seus direitos, oferecendo aos suábios licença para o funcionamento de escolas em língua alemã de nível médio e superior como uma forma de tê-los como aliados (ELFES, 1971).

Assim, em março de 1941, quando a lugoslávia entra oficialmente na guerra, numa campanha decisiva contra a Rússia, os suábios foram envolvidos pelo fascínio de libertação que a guerra prometia, ora por iniciativa própria, ora forçados. Anteriormente membros de minorias do exército iugoslavo, os suábios foram integrar o exército alemão (ELFES, 1971). 
Com o fim da Segunda Guerra Mundial, a Áustria, país que recebeu os povos de descendência alemã, estava com suas cidades destruídas. As pessoas passaram a viver aglomeradas, sem perspectiva de futuro.

Muitos suábios que sobreviveram à guerra e ficaram nos campos de refugiados da Europa não tinham mais para onde ir, pois tornaram-se apenas exilados políticos, sem Pátria, na Áustria ${ }^{5}$. Com o passar do tempo, o governo austríaco começou a ver no grupo um potencial de mão-de-obra para reconstruir o país devastado pela guerra, visto que a maioria da população masculina estava presa, em consequência do apoio à Alemanha (JAERGER, 1998).

Em conformidade com Elfes (1971), ao final do ano de 1944, todos de descendência alemã foram obrigados a fugir do sudeste da Europa, abandonando suas terras, casas e tudo o que lá possuíam. Fundamentados em leis recém criadas, que visavam intensificar a expansão da União Soviética em outros países e, expulsar os descendentes alemães e estrangeiros, muitos suábios foram usados para dívidas de guerra com trabalhos forçados na mineração. A Hungria e a Romênia também colocaram à disposição da Rússia homens e mulheres como força de trabalho (JAERGER, 1998).

Em 1949, o parlamento austríaco retoma a discussão sobre os refugiados e exilados quanto à legislação anteriormente aprovada sobre os Volksdeutsche e, em 17 de julho de 1952, novas leis foram deliberadas, devolvendo-Ihes alguns direitos e alguns benefícios sociais (JAERGER,1998).

${ }^{5}$ Entrevista concedida em julho de 2003. 


\section{RELATOS DE EXPERIÊNCIAS: OS SUÁBIOS DO DANÚBIO DE ENTRE RIOS, GUARAPUAVA/PR, AINDA NA EUROPA}

O senhor Peter Weckl ${ }^{6}$, em entrevista, relata que sua família fugiu da Romênia no início de setembro de 1944, pois até essa ocasião esse país era aliado de Hitler e, ao final do mesmo mês, a Romênia aliou-se a Stalin. Nesse contexto, os suábios tornaram-se inimigos da Romênia e passaram a ser perseguidos, sendo muitos deles mortos.

A família de Peter foi conduzida pelo exército alemão, que retornava da Grécia, depois de uma tentativa fracassada de tomar a cidade, que estava sob o comando de Stalin. Por volta de uma hora da manhã, o exército alemão bateu nas portas das casas dos descendentes alemães e os convidou a irem embora, alegando que no dia seguinte o exército de Stalin chegaria à região e quem não se retirasse poderia ser morto. Ainda segundo o entrevistado, por serem imigrantes, conservavam língua, tradições e costumes dos alemães, além de usufruírem do uso das terras do local.

De acordo com Elfes (1971), os suábios travaram uma luta cultural e não encontraram apoio nem mesmo na igreja, que estava a favor da "russificação" e da consciência nacionalista polonesa-eslava, e contra a tentativa de germanização dos suábios.

O que restou aos suábios, pós guerras, de acordo com o senhor Peter Weckl, foi fugir para salvar suas vidas e de seus entes queridos. Relata com alegria o fato de ter sobrevivido à viagem, já que era exceção entre a maioria de mulheres, idosos e crianças. Relembra que só podiam levar o que conseguissem carregar nos

\footnotetext{
${ }^{6}$ Peter Weckl é imigrante vindo da Romênia e morador da Colônia de Entre Rios. Nasceu em 31 de maio de 1935, naquele país. Veio para o Brasil com 16 anos e é um dos poucos imigrantes que não se considera agricultor. No começo, ele era sapateiro e ia para Guarapuava de bicicleta para consertar sapatos. É naturalizado brasileiro, trabalhou por 35 anos na Cooperativa Agrária. Entrevista realizada em Entre Rios, Guarapuava/PR, em 5 de maio de 2003.
} 
ombros (o Tratado de Potsdam, de 2 de agosto de 1945 impôs esse limite aos imigrantes).

Outro entrevistado foi o senhor Estefan Fasbinder ${ }^{7}$. Segundo o mesmo, quando sua família fugiu da Romênia, mãe, avô e irmãos, deixaram um irmão de 15 anos para cuidar da casa e dos animais. O reencontro aconteceu somente 45 anos depois. O que deixaram lá, segundo ele, o governo tomou: posses, casas, móveis, roupas, terras, etc. A figura 10 é uma recordação do entrevistado.

Figura 9 - Casa dos Fasbinder na Romênia

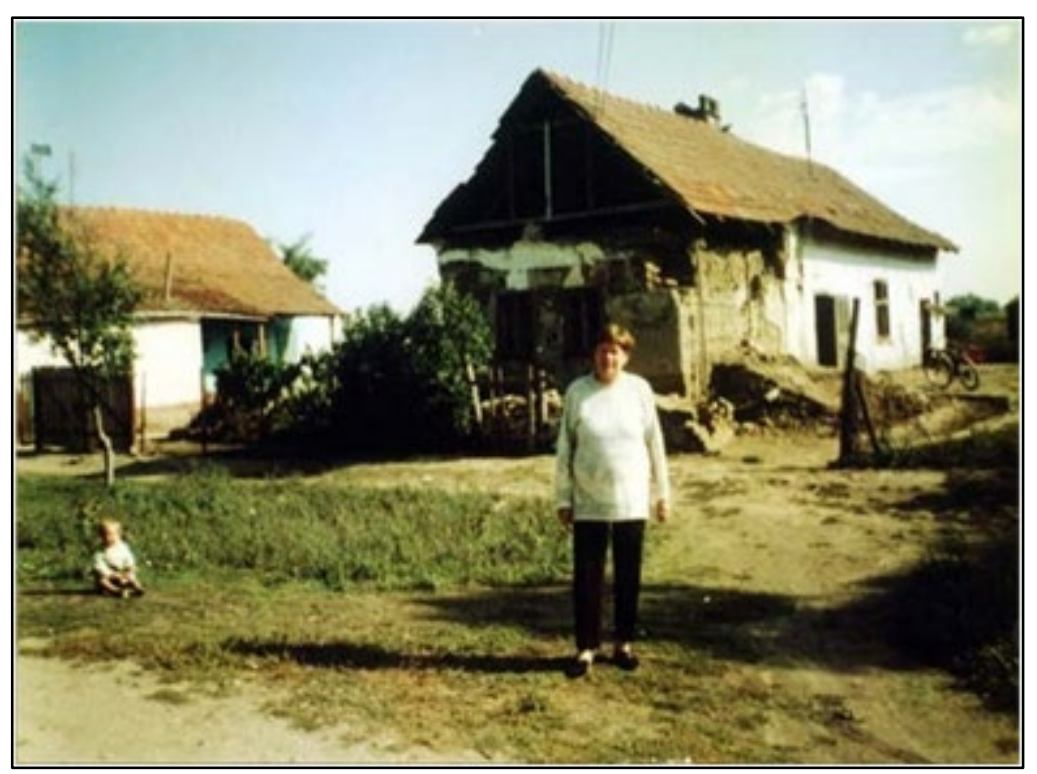

Fonte: Arquivo Pessoal de Estefan Fasbinder.

Outro relato é o do senhor Andréas Krueucher ${ }^{8}$. Segundo o mesmo a fuga foi muito rápida e eles não sabiam muito bem o que levar. A ordem era para que tivessem formas de se alimentar na viagem que duraria meses. Assim, abateram alguns porcos e outros foram vivos, sendo tocados por eles mesmos junto com as pessoas. Também levaram sacos de farinhas, que foram descartados ao longo da viagem por serem muito pesados para os cavalos, que também passam por fome e exaustão.

\footnotetext{
${ }^{7}$ Entrevista realizada em Entre Rios, Guarapuava/PR, em 15 de setembro de 2005.

${ }^{8}$ Entrevista realizada em Entre Rios, Guarapuava/PR, em 18 de abril de 2005.
} 
Um fato curioso relatado pelo senhor Estefan Fasbinder discorre sobre um menino que perdeu um pé do sapato e quis voltar para buscá-lo, já que a viagem seria longa. Não Ihe foi permitido, pois era o sapato ou a vida, e o menino fugiu com apenas um pé de sapato.

A fuga em carroças, de acordo com o entrevistado, tinha a proteção do exército alemão, que também acompanhava aqueles que seguiam a pé, como nos mostra a figura 11. Eram proibidos, no entanto, de usar as estradas, posto elas serem destinadas aos soldados soviéticos. Os caminhos abertos para a fuga encheram-se de fugitivos, com famílias sendo separadas em razão de alguns membros não estarem presentes no momento da ordem de fuga, que deveria ser imediata.

Figura 10 - Fuga de imigrantes suábios em carroças

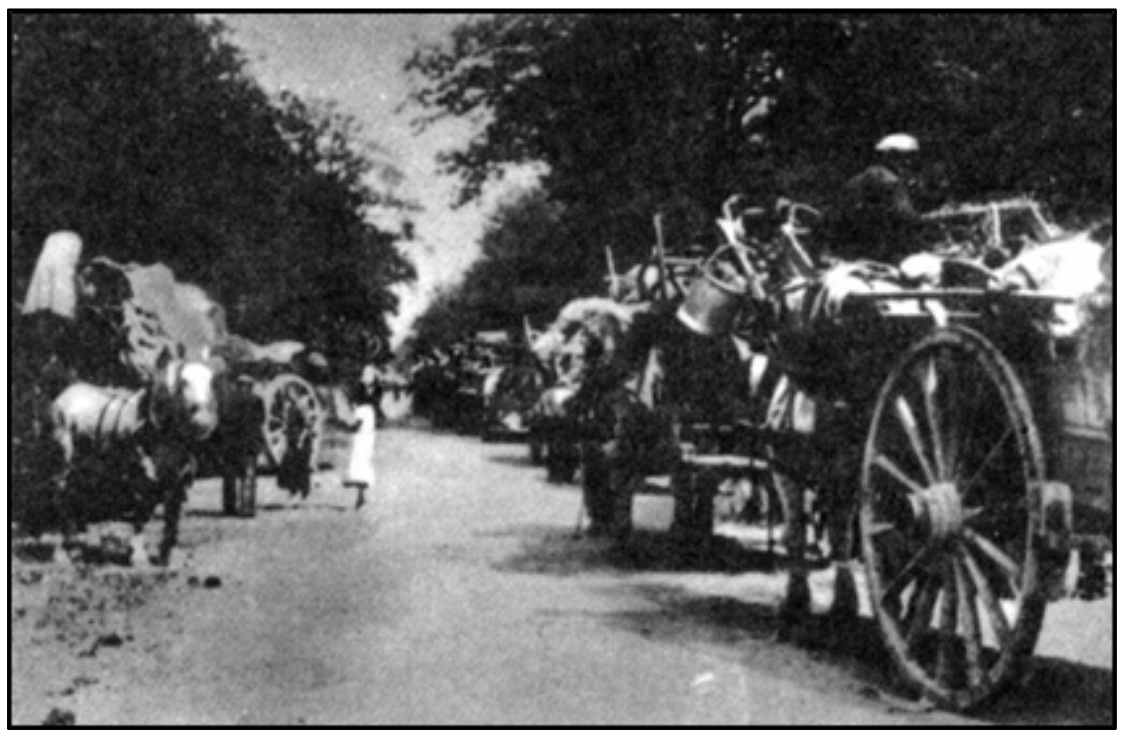

Fonte: Raymond Cartier (1977, p. 65).

De acordo com o relato do senhor Karl Keller ${ }^{9}$, a convivência entre os suábios, eslavos e magiares era muito boa na Croácia. Ele relata que quando começou a Segunda Guerra os homens da vila trabalhavam no campo durante o dia e a noite saiam atrás de inimigos (nazistas e russos), e até os convidavam para ir junto lutar

\footnotetext{
${ }^{9}$ Entrevista realizada em Entre Rios, Guarapuava/PR, em15 de setembro de 2005.
} 
ou falavam para suas mulheres "diga a seu marido para vir lutar conosco", mesmo sabendo que eles eram obrigados a entrar no exército alemão.

Ainda de acordo com o entrevistado, os moradores nativos criaram milícias que lutavam tanto contra os soldados nazistas como a favor (os croatas católicos colaboraram com os nazistas), como contra os soldados russos do exército vermelho e, às vezes, até entre eles mesmos, posto haver divergências entre eles. No entanto, quando era preciso lutavam juntos para se livrar da tentativa de ocupação do exército alemão e da violência dos russos soviéticos.

Segundo ainda o senhor Keller, a princípio nada faziam contra os suábios. No entanto, a situação começou a agravar-se com a possibilidade de a Alemanha perder a guerra. A situação era no conjunto violenta, de acordo com ele, e onde os russos atacavam, estupravam as mulheres e depois matavam a todos, roubando o que podiam levar e queimando o que restava (esta era uma tática de guerra para o inimigo ainda vivo não ter o que comer). Foi dessa situação que os suábios fugiram ou foram expulsos, conclui.

De acordo com os estudiosos aqui utilizados, em especial Elfes (1971), podese definir como característica peculiar do povo alemão-suábio as migrações, sendo que estas os levaram para o Leste e o Sudeste da Europa e para outros países, como o Brasil. O destaque, no entanto, é que a migração não tinha para os alemães-suábios o significado de domínio ou de guerra, mas sim de colonização, de recomeço e de construção de suas identidades no território, ou seja, retomada de suas territorialidades.

\section{CONSIDERAÇÕES FINAIS}

A vinda dos alemães suábios para o Brasil está fortemente ligada às duas Grandes Guerras Mundiais (a $1^{\circ}$ em 1914 - 1918 e a $2^{\circ}$ em 1939 - 1945) e suas consequências, principalmente, da Segunda. Porém, outros fatores favoreceram a saída destes imigrantes do continente Europeu. 
O texto aqui apresentado, busca demonstrar justamente como se deu a ocupação e a mobilidade dos suábios pelo território banhado pelo rio Danúbio, ora forçados a mudanças ora optando pelas mesmas, mas sempre em função de conflitos geopolíticos pelo território.

Ao fim da Primeira Guerra Mundial, por exemplo, houve a divisão do Império Áustro-Húngaro como dívida por ter sido derrotado, e o povo que fazia parte de uma só nação foi distribuído entre três países sucessores: Hungria, Romênia e lugoslávia. Além disso, a prática de obrigar as pessoas ao trabalho forçado era usada de forma generalizada em todos os períodos apresentados no texto. Outros aspectos foram mais singulares e resultantes de elementos mais específicos a cada momento histórico, mas nada como as transformações político-administrativas no território.

Esse foi, de longe, o principal motivo pelos quais os descendentes de alemães decidiram fugir das cidades ou países onde moravam. Alguns ainda permaneceram na Europa, apesar das restrições impostas, mas muitos, percebendo a dificuldade em ir para Alemanha e reconquistar seus direitos de cidadãos, principalmente pelo medo do comunismo, só tiveram como opção fugir para países de vários continentes diferentes. A procura de uma nova pátria, foram para a Argentina, Canadá, Estados Unidos, Venezuela, Paraguai, Chile, Brasil, além de Grã-Bretanha, França, Austrália, Bélgica e Israel.

No final do século XIX, os descendentes alemães que imigraram para os Estados Unidos formaram lá uma comunidade de suábios do Danúbio, segundo Abeck (1980), semelhante à colônia Suábia de Entre Rios, no Brasil.

Considera-se, assim, que os suábios do Danúbio são uma mistura de vários povos que têm em comum a etnia, a cultura e a língua alemã, sendo em grande maioria agricultores, indiferentemente dos países onde se fixaram. Na Europa, antes da saída para o novo território, considerando-se o grupo chegado a Guarapuava, o objetivo desse texto foi o de perceber suas histórias pela leitura 
geopolítica do território ou da desterritorialização e reterritorialização ao longo do rio Danúbio.

\section{REFERÊNCIAS}

ABECK, H. A colaboração germânica no Paraná nos últimos 50 anos (1929-1979). Curitiba: Gráfica Wunderlich, 1980.

ABREU, M. de A. Geografia Histórica do Rio de Janeiro (1502-1700). Rio de Janeiro: Andrea Jakobsson Estúdio \& Prefeitura do Município do Rio de Janeiro, 2010, 420 p.

ALBUQUERQUE, M. M.; REIS, A. F.; CARVALHO, C. D. de. Atlas Histórico Escolar. Rio de Janeiro: FENAME, 1980.

CARTIER, R. A segunda guerra mundial. $3^{\mathrm{a}}$ Ed. Rio de Janeiro: Editora Primor,1977.

CLARKSON, S. History of German Settlements in Southern Hungary. FEEFHS, 1997

COOPERATIVA AGRÁRIA MISTA ENTRE RIOS. Entre Rios: Documentário ilustrado da colonização suábios danubiana. Guarapuava: Cartgraf Campinas Artes Gráficas Editora Ltda, 1979.

CRESSWELL, T. On the move: mobility in the modern western world. New York: Routledge, 2006.

DIAS, C. O mundo em transição. Revista Aventuras na História. 14a ed. São Paulo: Editora Abril, 2005, p. 11-15.

ELFES, A. Suábios no Paraná. Curitiba: Cooperativa Agrária Mista Entre Rios Ltda, 1971.

ENCICLOPÉDIA BARSA. Rio de Janeiro - São Paulo: Enciclopédia Britânnica, p. 219- 237, 1987

FRIEDRICH, M. Gênese e evolução do Distrito de Entre Rios em Guarapuava-PR e a Cooperativa Agrária. 2005. Monografia (Mestrado em Geografia) - Universidade Estadual do Centro-Oeste, Guarapuava, 2005.

GIBRIN, M. A cobiça saiu cara. Revista Aventuras na História. 14ª ed. São Paulo: Editora Abril, 2005, p. 58.

GUILHERME, P. Terror sobre rodas. Revista Aventuras na História. 14a ed. São Paulo: Editora Abril, 2005, p. 54-55.

HAESBAERT, R. O mito da desterritorialização: do "fim dos territórios" à multiterritorialidade. Rio de Janeiro: Bertrand Brasil, 2004. 
JAERGER, J. R. O Desenvolvimento do Complexo Agro-Industrial da Cooperativa Agrária Mista Entre Rios Ltda. 1998. Monografia (Especialização em Geografia Rural) - Universidade Estadual Do Centro-Oeste, Guarapuava, 1998.

KOOP, H. The Last Generation Forgotten and Left to Die: The Postwar Memoirs of a Child: the History of the Danube Swabians in Word and Pictures. Hardcover - 2003.

MONTGOMERY, F.J. Tradução: Tibor Rabóczkay e Edit Piza. Hungria satélite contra a vontade. São Paulo: Com-Arte, 1999.

NILSON, P. Terror sobre rodas. Revista Aventuras na História. 14 a ed. São Paulo: Editora Abril, 2005, p. 55.

PAIKERT, G. C. The Danube Swabians. Haia: Martinus Nijhoff, 1967.

REVISTA DESPERTAI. 1914 Tiros que ainda abalam o mundo. Cesário Lange, SP: Torre de Vigia da Bíblia e Tratados. Agosto, 1994

RODRIGUES, I. A agonia de um gigante. Revista Aventuras na História. São Paulo: Editora Abril, fev., 2005, p. 23. (Coleção Grandes Guerras - Invasões Bárbaras).

SANTOS JUNIOR, W. R dos. Geografia I: Epistemologia, Política e Meio Ambiente. São Paulo, Editora Saraiva, 2016.

SILVA, M. da. Territórios conservadores de poder no centro-sul do Paraná. 2005. 263 p. Tese (Doutorado em Geografia) - Universidade Estadual Paulista, Faculdade de Ciências e Tecnologia, Presidente Prudente, 2005.

VICENTINO, C. História memória viva - da Pré-História à Idade Média. São Paulo: Scipione, 1996.

YUDENITSCH, N. A fúria que veio a galope. Revista Aventuras na História. 14. ed. São Paulo: Editora Abril, 2005, p. 25-29.

1 - Márcia da Silva:

Doutora em Geografia

https://orcid.org/0000-0002-2742-1396 - marcia.silvams@gmail.com

Contribuição: Elaboração do referencial teórico-conceitual, articulação com os resultados práticos da pesquisa e realização de entrevistas.

\section{2 - João Matheus Afinovicz da Lima:}

Graduado em Geografia https://orcid.org/0000-0002-0668-1324 - joaoafinovicz158@gmail.com Contribuição: Realização de trabalho de campo (coleta de dados, entrevistas), análise e escrita dos resultados. 


\section{3 - Larissa Aparecida Dionizio:}

Discente de Mestrado do Programa de Pós-Graduação em Geografia (PPGG), graduada em Geografia

https://orcid.org/0000-0002-1458-695X - lara_dionizio@hotmail.com

Contribuição: Realização de trabalho de campo (coleta de dados, entrevistas), análise e escrita dos resultados.

\section{Como citar este artigo}

SILVA, M. da; LIMA, J. M. A. da; DIONIZIO, L. A. Os Suábios do Danúbio e a geopolítica de ocupação do território - da Europa ao Brasil. Geografia Ensino \& Pesquisa, Santa Maria, v. 25, e42, p. 1-30, 2021. DOI 10.5902/22364994555086. Disponível em: https://doi.org/10.5902/2236499455086. Acesso em: dia mês abreviado. ano. 